\title{
CARBON SEQUESTRATION AND SPATIAL DIFFERENTIATION CHARACTERISTICS OF URBAN FOREST IN CHINA
}

\author{
LI, F. X. ${ }^{1,2^{*}}-$ SHI, H. ${ }^{1}-$ ZHAO, J. S. ${ }^{3}-$ FENG, X. G. ${ }^{2}-$ LI, M. ${ }^{2}$ \\ ${ }^{1}$ School of Environmental and Municipal Engineering, Xi' an University of Architecture and \\ Technology, Xi'an 710055, Shaanxi, China \\ (H. Shi: e-mail:497394178@qq.com; phone: +86-137-7216-2185; fax:+86-29-8220-5813) \\ ${ }^{2}$ School of Architecture, Xi'an University of Architecture and Technology \\ Xi'an 710055, Shaanxi, China \\ (X. G. Feng: e-mail: 1010425832@qq.com; phone: +86-137-5988-6561; fax: +86-29-8220-5813; \\ M. Li: e-mail: 475983882@qq.com; phone: +86-135-7212-2767; fax: +86-29-8220-5813) \\ ${ }^{3}$ School of Land and Resources Engineering, Kunming University of Science and Technology \\ Kunming 650093, Yunnan, China \\ (J. S. Zhao: e-mail: 1429620189@qq.com; phone: +86-137-0844-1869; fax: +86-871-6821-6333) \\ *Corresponding author \\ F.X. Li: e-mail: lifengxiasky@163.com; phone: +86-159-2956-6258; fax: +86-29-8220-5813 \\ (Received 30 $0^{\text {th }}$ Sep 2017; accepted $20^{\text {th }}$ Feb 2018)
}

\begin{abstract}
Based on large-scale data measured in quadrats, and using remote sensing images, the author analyzed the spatial differentiation characteristics of carbon storage and carbon density of forest vegetation in the north foot of the Qinling Mountains in China, by combining an allometric growth model with spatial analysis using a Geographic Information System. The results showed that the average carbon density of forest vegetation in the main urban area in Xi' an occurred in the order: cultural and educational green space > scenic-area green space > road green space > industrial green space > residential green space. The average carbon density of arbor forest was $6.308 \mathrm{~kg} / \mathrm{m}^{2}$. The carbon storage capacity varied in the order: green land in cultural and educational districts > scenic-area green space > road green space > residential green space > industrial green space. The total amount of carbon storage in the arbor forest was $519,180 \mathrm{t} \mathrm{C}$. The spatial distribution pattern of carbon density in the arbor layer in the Xi'an administrative region was not balanced, showing high value in a southern suburb and low value in a northern suburb. Increasing forest vegetation, improving the quality of the forest structure, and increasing the three-dimensional green quantity of urban forest are effective ways to improve urban environments and to enhance carbon sequestration by forests.
\end{abstract}

Keywords: forest vegetation, carbon storage, carbon density, spatial differentiation, 3S technology

\section{Introduction}

Forests are the main terrestrial ecosystem on Earth, accounting for $77 \%$ of the carbon stored globally as terrestrial vegetation. Urban vegetation is an important component of urban ecosystems, providing important ecological services (Niemelä et al., 2010; Coley et al., 1997) such as helping to regulate climate change and maintain the global carbon balance (Beer et al., 2010; Bonan, 2008; Bousquet et al., 2000). Therefore, accurately evaluating carbon sequestration by forests is significant to better management of the carbon cycle and can simultaneously provide a scientific basis for improving the ability to cope with global climate change.

There have been many international studies estimating carbon sequestration and carbon storage by forest vegetation (Dixon et al., 1994; Fang et al., 2001; Janssens et al., 2003; Jo and McPherson, 1995; McPherson, 1998; Nowak, 1993; Nowak and 
Crane, 2002; Pacala et al., 2001; Piao et al., 2005). Nowak researched California urban tree carbon storage and found that in Auckland (with tree coverage of 21\%); trees could store 11.0 tons of carbon per hectare (Nowak, 1993). McPherson's research in Sacramento showed that six million urban trees stored eight million tons of $\mathrm{CO}_{2}$, with an average $\mathrm{CO}_{2}$ sequestration of 31 tons per hectare and 0.92 tons per hectare per year (McPherson, 1998). Jo and McPherson researched the carbon sequestration of two residential areas in northern Chicago, and found that the carbon sequestration capacity of arbors and shrubs was $1.03-4.42 \mathrm{~kg} / \mathrm{m}^{2}$, and that the carbon sequestration of each residential area was $513.5-3249.5 \mathrm{~kg}$ (Jo and Mcpherson, 1995). Based on the urban green coverage, Nowak and Crane researched the carbon storage of 10 cities in the United States. The results showed that urban trees stored about 700 million tons of carbon per year, the annual carbon sequestration capacity was 22.8 million tons, and the average carbon sequestration capacity of urban trees was 25.1 tons per hectare. However, the urban vegetation carbon sequestration capacity was significantly different between cities (Nowak and Crane, 2002). Scholars have researched the carbon storage of forest vegetation in Liaoning Province, Hunan Province, Shaanxi Province, Sichuan Province, and Guangzhou City (Dongsheng et al., 1998; Huang, et al., 2000; Liu et al., 2000; Ma et al., 2012; Liu, et al., 2016; Wang et al., 2001; Zhen, et al., 2014), revealing the amount of carbon storage in the aboveground part of forest vegetation in China. However, inconsistent research methods resulted in large differences in research results, so there was still substantial uncertainty. Carbon sequestration by urban vegetation is mainly studied through ground investigation and estimation via remote sensing (Yan et al., 2016). China's forest vegetation types are diverse and complex. In general, there are few data in this field; therefore, it is necessary to select appropriate research methods to estimate the carbon storage of forest vegetation in provinces and cities accurately, to improve credibility and accurately quantify carbon sequestration by forest vegetation (Fang, 2000; Tans et al., 1990; Houghton et al., 1994; Siegenthaler and Sarmiento, 1993).

The ecological environment on the northern foot of the Qinling Mountains is fragile, and the forest vegetation has distinct regional characteristics and specialties. However, at present, estimates of the carbon storage by forest vegetation on the north foot of the Qinling Mountains are rare. For this reason, we used high-resolution remote sensing image data covering a wide range of quadrats to analyze the spatial differentiation of the carbon storage and density of the Xi'an forest vegetation in a semi-humid region on the northern foot of the Qinling Mountains to try to explore its drivers. This was done using GIS technology, to provide a scientific basis for research on the carbon-storage of forest ecosystems at national level, to provide a scientific basis for improving the ability of those in cities to cope with global climate change, and to evaluate and plan urban green space ecosystem services to achieve sustainable urban development.

\section{Materials and methods}

\section{Overview of research areas}

Xi'an City on the north foot of the Qinling Mountains is a city typical of semihumid areas in China. It is located in the eastern part of northwest China and on the central part of the Guanzhong Plain. The geographical coordinates are $33^{\circ} 42^{\prime}$ to $34^{\circ}$ $45^{\prime} \mathrm{N}$, and $107^{\circ} 40^{\prime}$ to $109^{\circ} 49^{\prime} \mathrm{E}$. The area is subject to a warm-temperate semi- 
humid continental monsoon climate. The average elevation is $424 \mathrm{~m}$, the average annual temperature is $13.3{ }^{\circ} \mathrm{C}$, the average precipitation is $604.2 \mathrm{~mm}$, and the average humidity is $69.6 \%$. Its jurisdiction districts include Beilin, Yanta, Xincheng, Weiyang, Lianhu, Baqiao, Chang'an, Lintong, Yanliang, and Gaoling; and include the counties of Huxian, Lantian, and Zhouzhi. These ten districts and three counties cover an area of $10,108 \mathrm{~km}^{2}$. The main urban areas are in Beilin District, Yanta District, Xincheng District, Weiyang District, Lianhu District, and Baqiao District (urban area of 822.28 $\mathrm{km}^{2}$ ). The geographical location and administrative map of the research area is shown in Figure 1. The green space rate, green coverage rate, and per capita public green area of Xi'an are currently $31 \%, 39.82 \%$, and $7.59 \mathrm{~m}^{2}$, respectively. The basic characteristics of the vegetation are rich diversity and a number of floral preserves in which there are many tectonic residual plants. The arbor forest area in the main urban area in Xi' an is $75,959,475.45 \mathrm{~m}^{2}$.

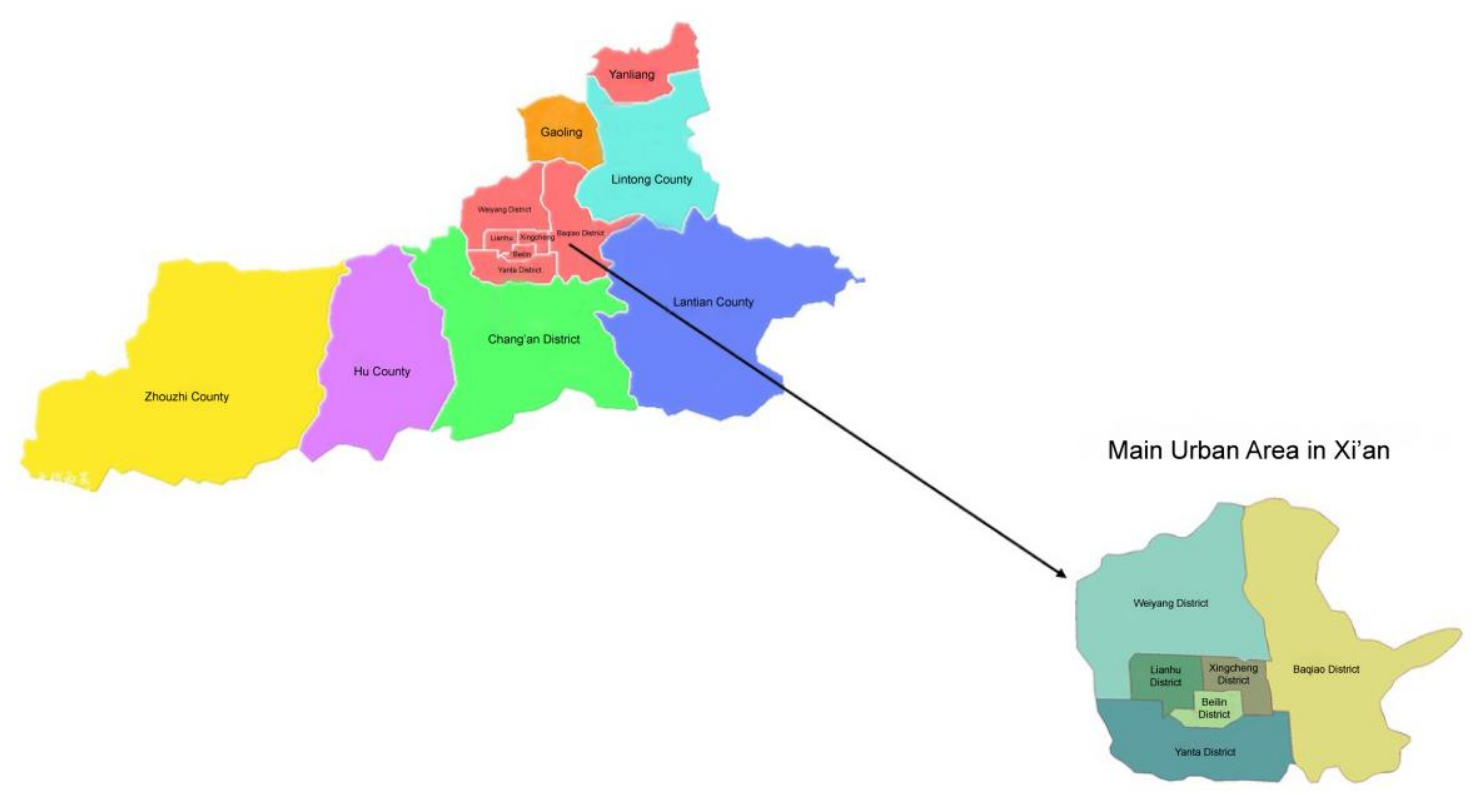

Figure 1. Geographic location and scope of the research area

\section{Data source and quadrat setting}

The basic information used in this research includes QuickBird high-resolution remote sensing image data, Landsat 8 data of Xi'an in July 2015, and Xi'an administrative map data from large-scale quadrats. Supported by $3 \mathrm{~S}$ (Geographic Information System, Remote Sensing, and Global Positioning System) technology combined with field investigation, the author classified land use with the remote sensing software Ecognition, and extracted urban green information for Xi'an. Then the author divided the green space into road green space, residential green space, scenic-area green space, cultural and educational green space, and industrial green space (Fig. 2) using the GIS software ARCGIS. Because the arbor forest is the main contributor to carbon storage by forest vegetation, this paper mainly researched the carbon storage of arbor forest in the main urban areas of Xi'an. 


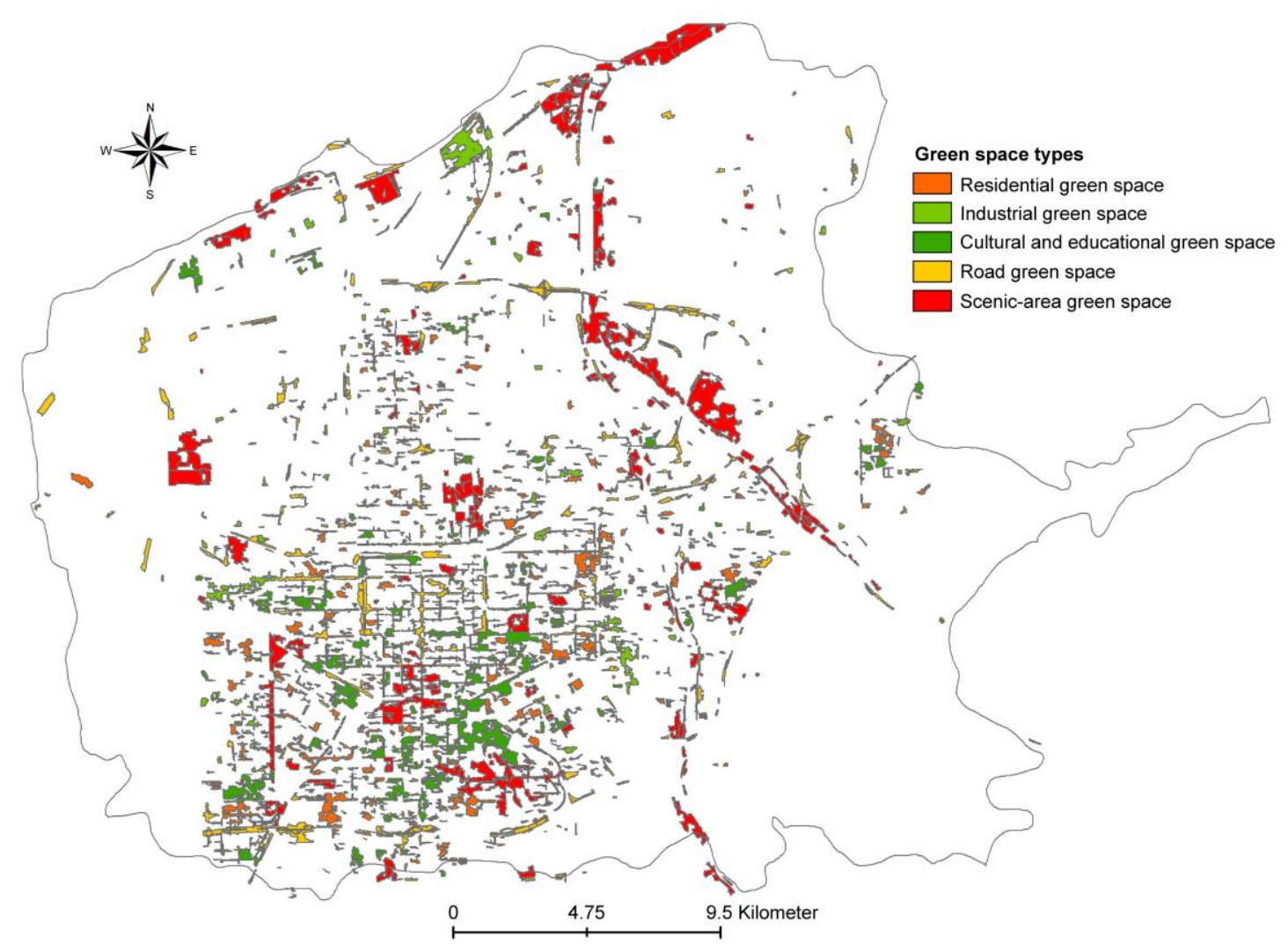

Figure 2. Classification map of urban green space in Xi'an

According to the distribution characteristics of urban plants and the actual situation of parks, roads, residential areas, cultural and educational areas, and industrial areas, the location of field investigations and the number of quadrats were determined. The size of the park quadrats was set to $20 \times 20 \mathrm{~m}$, and the distance between two adjacent quadrats was not less than $150 \mathrm{~m}$, with a total of 40 quadrats from 20 parks including Xingqinggong Park, City Sports Park, and Fengqing Park being surveyed. For the setting of road quadrats, based on the length of roads and the configuration of the vegetation, the author investigated the specific situations of trees on roads $(100 \times 10 \mathrm{~m})$ with a total of 140 quadrats on 113 roads (e.g., Friendship Road, Taiyi Road, and Wenjing Road) being investigated (Fig. 3). For the setting of residential quadrats, each quadrat contained a residential building and its surrounding street trees and green belt, and the area of a quadrat plot was determined based on actual situations, with a total of 23 quadrats in 23 residential areas being investigated (including Dongfang Yayuan, Dingxin Garden, and Hairong Yango) (Fig. 4). The school quadrat was set to $20 \times 20 \mathrm{~m}$ (same method as for the park quadrats) with a total of 31 quadrats at 18 schools being investigated (including Xi'an University of Architecture and Technology, Xi'an Physical Education University, and Xi'an Jiaotong University). The industrial quadrats were set to $20 \times 20 \mathrm{~m}$ in a total of six industrial areas (e.g., PetroChina Changqing Oilfield Company, China Typical Industries Group Co., Ltd, Xi'an Electromechanical Vehicle Parts Factory). The author investigated the type, quantity, and growth condition of trees with diameter at breast height $(\mathrm{DBH})$ over $5 \mathrm{~cm}$, and measured the height $(\mathrm{H}$, height from the ground to the top of the canopy) and DBH (D, the diameter of trunk at $1.3 \mathrm{~m}$ above the ground) of each tree. There were 240 quadrats. 


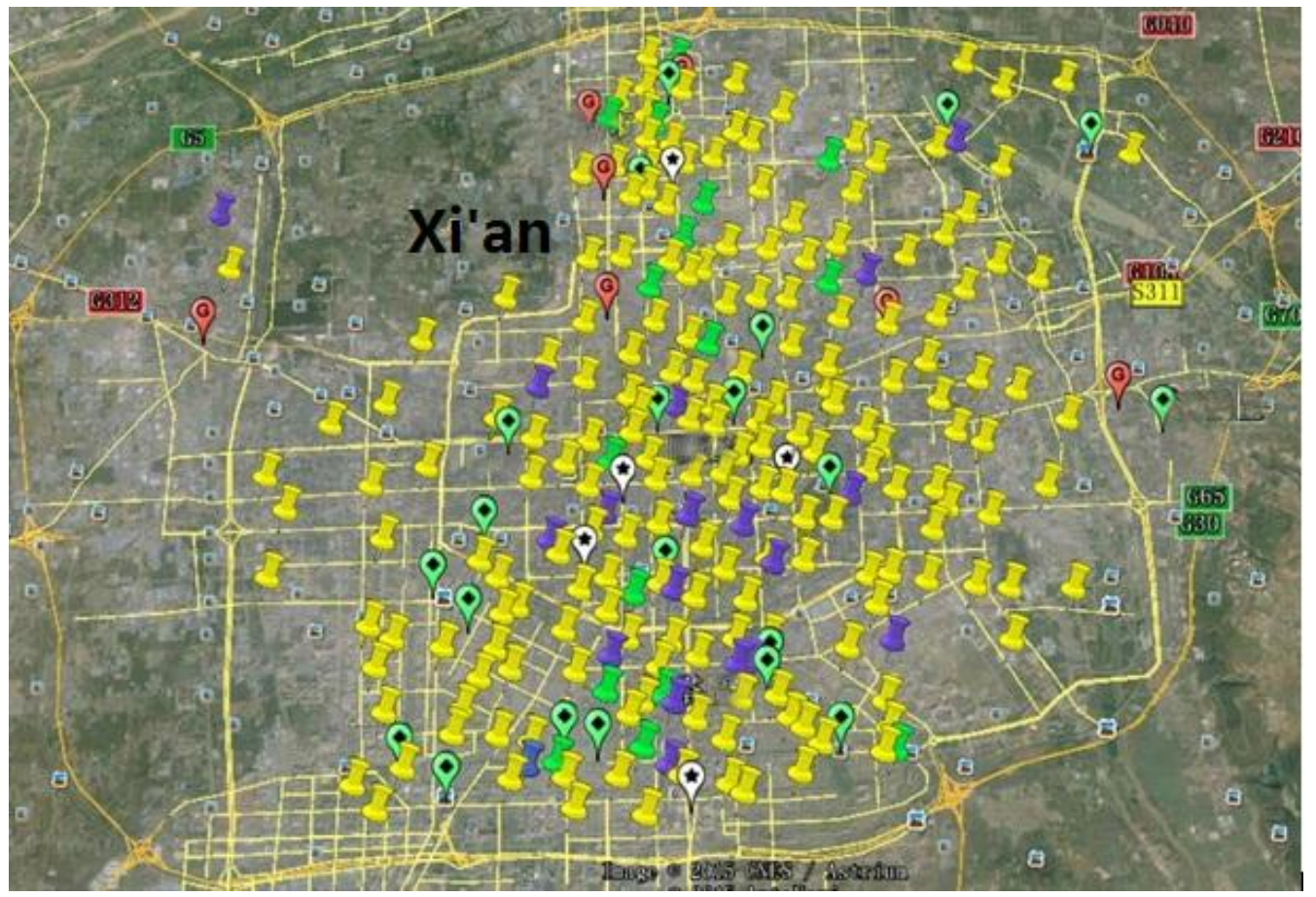

Figure 3. Sample layout map
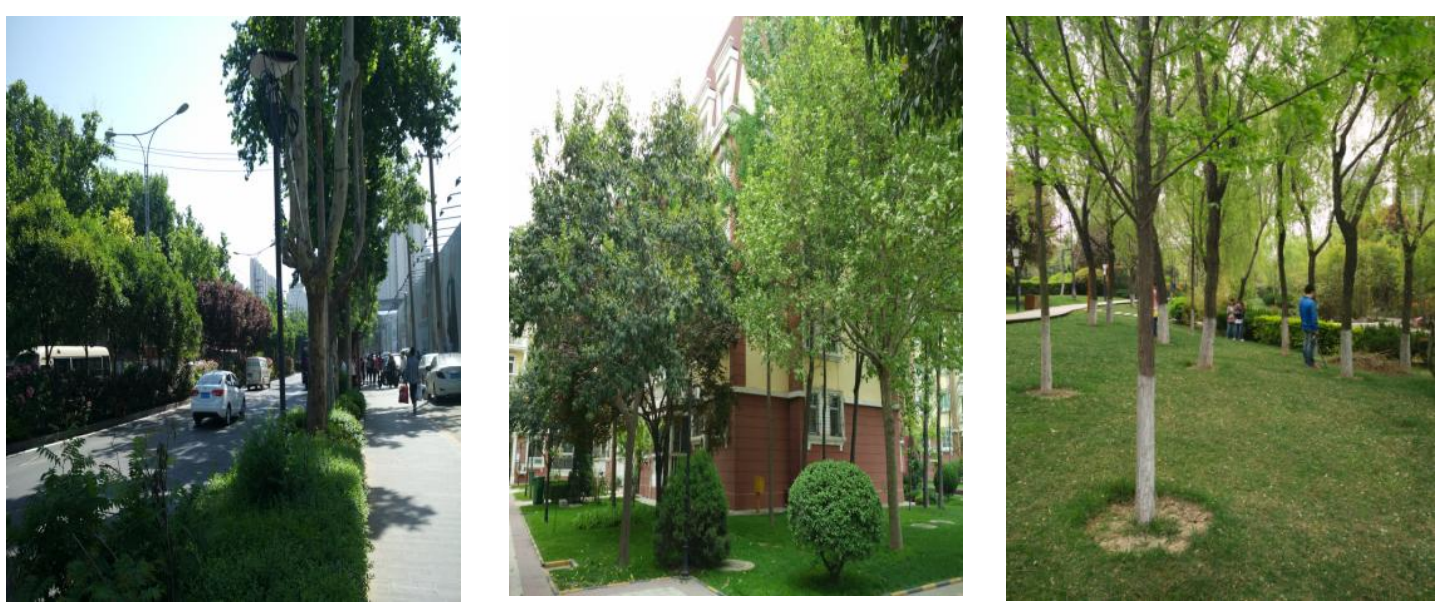

Figure 4. Examples of some of the residential areas investigated

\section{Estimation of forest vegetation biomass}

Vegetation biomass is the unit of vegetation carbon storage. The current methods for estimating forest vegetation biomass include the variable biomass expansion factor method, the volume-derived method (i.e., the regression model of biomass and volume), the allometry equation, and remote sensing inversion. Of these, the biomass expansion factor (BEF) and the stand volume (x) establish a power exponential function relation and a reciprocal function relation, respectively, as shown in Equations 1, 2, and 3:

$$
B E F=a x^{-b}
$$




$$
B E F=a+\frac{b}{x}
$$

where $\mathrm{a}$ and $\mathrm{b}$ are constants. The regression model was established by applying the volume-derived method:

$$
Y=a V+b
$$

where $\mathrm{Y}$ is the biomass density, $\mathrm{V}$ is the stand volume density, and $\mathrm{a}$ and $\mathrm{b}$ are constants. In this research, according to the measured data from field sampling quadrats, the allometry equation of urban greening tree species was adopted to calculate the vegetation biomass. The allometry equation of urban greening tree species is shown in Table 1, where $\mathrm{B}, \mathrm{D}$, and $\mathrm{H}$ represent biomass, diameter at breast height, and plant height, respectively. For tree species without corresponding models, parameters of similar species of trees were used instead, according to the actual situation in each region.

Table 1. Allometry equations of greening tree species

\begin{tabular}{c|c|c}
\hline No. & Greening tree species & Calculation formula \\
\hline 1 & Cinnamomum camphora & $\mathrm{B}=0.937+0.037 \mathrm{D}^{2} \mathrm{H}$ \\
2 & Populus simonii & $\mathrm{B}=0.015\left(\mathrm{D}^{2} \mathrm{H}\right)^{1.032}$ \\
3 & Styphnolobium japonicum & $\mathrm{B}=0.714+0.03 \mathrm{D}^{2} \mathrm{H}$ \\
4 & Ligustrun lucidum & $\mathrm{B}=0.907+0.010 \mathrm{D}^{2} \mathrm{H}$ \\
5 & Metasequoia glyptostroboides & $\mathrm{B}=\mathrm{Exp}[-0.8168+2.15491 \mathrm{gD}]$ \\
6 & Pinus massoniana & $\mathrm{B}=0.1309 \mathrm{D}^{2.4367}$ \\
7 & Salix sp. & $\mathrm{B}=0.178 \mathrm{D}^{2.581}$ \\
8 & Sapindus mukorossi & $\mathrm{B}=-3.672+0.4815 \mathrm{D}^{2}$ \\
9 & Ginkgo biloba & $\mathrm{B}=-0.684+0.090 \mathrm{D}^{2} \mathrm{H}$ \\
10 & Cedrus deodara & $\mathrm{B}=1.26\left(0.3721 \mathrm{D}^{1.2928}+0.2805 \mathrm{D}^{1.3313}\right)$ \\
11 & Koelreuteria paniculata & $\mathrm{B}=0.915+0.100 \mathrm{D}^{2} \mathrm{H}$ \\
12 & Broussonetia papyrifera & $\mathrm{B}=1.7579\left(\mathrm{D}^{2} \mathrm{H}\right)^{1.5784}$ \\
13 & Lagerstroemia indica & $\mathrm{B}=0.895+0.035 \mathrm{D}^{2} \mathrm{H}$ \\
14 & Platanus acerifolia & $\mathrm{B}=0.0690\left(\mathrm{D}^{2} \mathrm{H}\right)^{0.9133}$ \\
15 & Cupressaceae & $\mathrm{B}=0.000030507+0.000033947 \mathrm{D}^{2} \mathrm{H}+0.00012531\left(\mathrm{D}^{2} \mathrm{H}\right)^{0.733}$ \\
16 & Liquidambar formosana & $\mathrm{B}=0.043\left(\mathrm{D}^{2} \mathrm{H}\right)^{0.994}$ \\
17 & Ulmus pumila & $\mathrm{B}=0.1458\left(\mathrm{D}^{2} \mathrm{H}\right)^{0.8191}$ \\
18 & Eucommia ulmoides & $\mathrm{B}=1.687+0.046 \mathrm{D}^{2} \mathrm{H}$ \\
19 & Paulownia tomentosa & $\mathrm{B}=0.077180 \mathrm{D}^{2.27598}$ \\
20 & Hardwoods & $\mathrm{B}=\mathrm{Exp}(-3.5618+2.6645 \ln \mathrm{D})$ \\
21 & Softwood & $\mathrm{B}=\mathrm{Exp}(-2.2796+2.2874 \ln \mathrm{D})$ \\
\hline
\end{tabular}

\section{Estimation of carbon storage and carbon density of forest vegetation}

Based on the high-resolution satellite remote sensing image data for Xi'an, for this paper, we combined field investigation information and data from $3 \mathrm{~S}$ technology. The forest vegetation biomass, which was calculated using the allometry equation of 
greening-tree species, was multiplied by carbon content to estimate urban forest carbon storage, as shown in Equation 4:

$$
C=B_{t} \times C_{c}
$$

where $\mathrm{C}$ is the forest vegetation carbon storage, $\mathrm{Bt}$ is the total biomass, and $\mathrm{Cc}$ is the forest vegetation carbon content. The author adopted the value of 0.5 used internationally (Ge et al., 2013). Carbon density refers to carbon storage per unit area. The carbon storage and carbon density of road green space, residential green space, scenic-area green space, cultural and educational green space, and industrial green space were analyzed quantitatively. Combined with definitions of the different types of green areas, ARCGIS was used to map the spatial distribution of carbon density and carbon storage of forest vegetation in Xi'an and to analyze spatial differentiation characteristics of forest vegetation carbon storage and carbon density in the main urban area in Xi'an.

\section{Results}

\section{Carbon storage analysis of arbor forest in Xi'an}

According to the measured carbon storage per unit area of road green space, residential green space, scenic-area green space, cultural and educational green space, and industrial green space, and the green area determined by ARCGIS, the carbon storage of the forest vegetation of the main urban area in Xi'an was calculated and is shown in Table 2.

Table 2. Carbon storage in the main urban area in Xi'an

\begin{tabular}{c|c|c|c|c|c}
\hline No. & Type & $\begin{array}{c}\text { Quadrat } \\
\text { number }\end{array}$ & $\begin{array}{c}\text { Average carbon } \\
\text { density } \mathbf{( k g / \mathbf { m } ^ { 2 } )}\end{array}$ & Area $\left(\mathbf{m}^{\mathbf{2}}\right)$ & $\begin{array}{c}\text { Carbon storage } \\
(\mathbf{k g})\end{array}$ \\
\hline 1 & Green space along roads & 140 & 4.76 & $15,633,211.593$ & $74,414,087.18$ \\
2 & Residential green space & 23 & 2.93 & $11,766,371.832$ & $34,475,469.47$ \\
3 & Scenic-area green space & 40 & 6.41 & $28,449,692.827$ & $182,362,531.02$ \\
4 & Cultural and educational green space & 31 & 14.24 & $14,816,815.179$ & $210,991,448.15$ \\
5 & Industrial green space & 6 & 3.20 & $5,293,384.019$ & $16,938,828.86$ \\
6 & Total number & 240 & & & $519,182,364.68$ \\
\hline
\end{tabular}

It can be seen from Table 2 that the order of average carbon density of the arbor layer in the main urban area in Xi'an was as follows: cultural and educational green space $>$ scenic-area green space > road green space > industrial green space > and residential green space. The average carbon density of the main urban area in Xi'an was 6.308 $\mathrm{kg} / \mathrm{m}^{2}$, higher than the average level of carbon density in Shaanxi Province. The carbon storage in the arbor layer of the main urban area in Xi'an occurred in the order: cultural and educational green space $>$ scenic-area green space $>$ road green space $>$ residential green space $>$ and industrial green space, and the green storage in the green space of cultural and educational districts was $210,990 \mathrm{t} \mathrm{C}$, a contribution of $40.6 \%$ to carbon sequestration of the arbor layer in main urban area of Xi'an. The carbon storage of scenic-area green space contributed $35.1 \%$ to carbon sequestration of arbor layer in the whole city. Carbon storage in road green space accounted for $14.3 \%$ of the total arbor 
trees in the whole city; while the carbon storage in residential green space accounted for $6.6 \%$ of the main urban area in Xi'an. The carbon storage in industrial green space accounted for $3.3 \%$ of the main urban area in Xi' an only; the total carbon storage of the main urban area in Xi' an was 519,180 t C.

The research showed that the arbor forest in cultural and educational areas and scenic areas in Xi'an played a leading role in carbon sequestration by forest vegetation in the main urban area in $\mathrm{Xi}$ 'an; the road forest made a general contribution to carbon sequestration function of the arbor layer in the main urban area in Xi'an. However, the arbor forest in residential and industrial areas made little contribution to carbon sequestration by forest vegetation. It can be seen that in the future, we should improve green space quality in residential areas, and follow the principle "people-oriented, ecology first". In residential landscape planning and design, we should pay attention to plant configuration, and try to choose appropriate local tree species, so as to improve the quantity of three-dimensional greenery and its ecological service functions, as well as to improve the residents' quality of life and happiness index. Simultaneously, when constructing industrial green space, we should arrange arbor-shrub-grass multi-layer garden plants with strong ecological function, especially vegetation to retain dust and absorb $\mathrm{SO}_{2}$. The objective is to increase the quantity of three-dimensional greenery and improve the ecological efficiency of green spaces. This should effectively improve the environmental quality of industrial areas.

\section{Carbon density analysis of forest vegetation in Xi'an}

The standard deviation (2.12) determined according to classical statistics was confirmed as the classification criteria of carbon density in forest vegetation in Xi'an. Moreover, the spatial distribution of carbon density of forest vegetation in Xi'an was drawn using ARCGIS software, as shown in Figure 5.

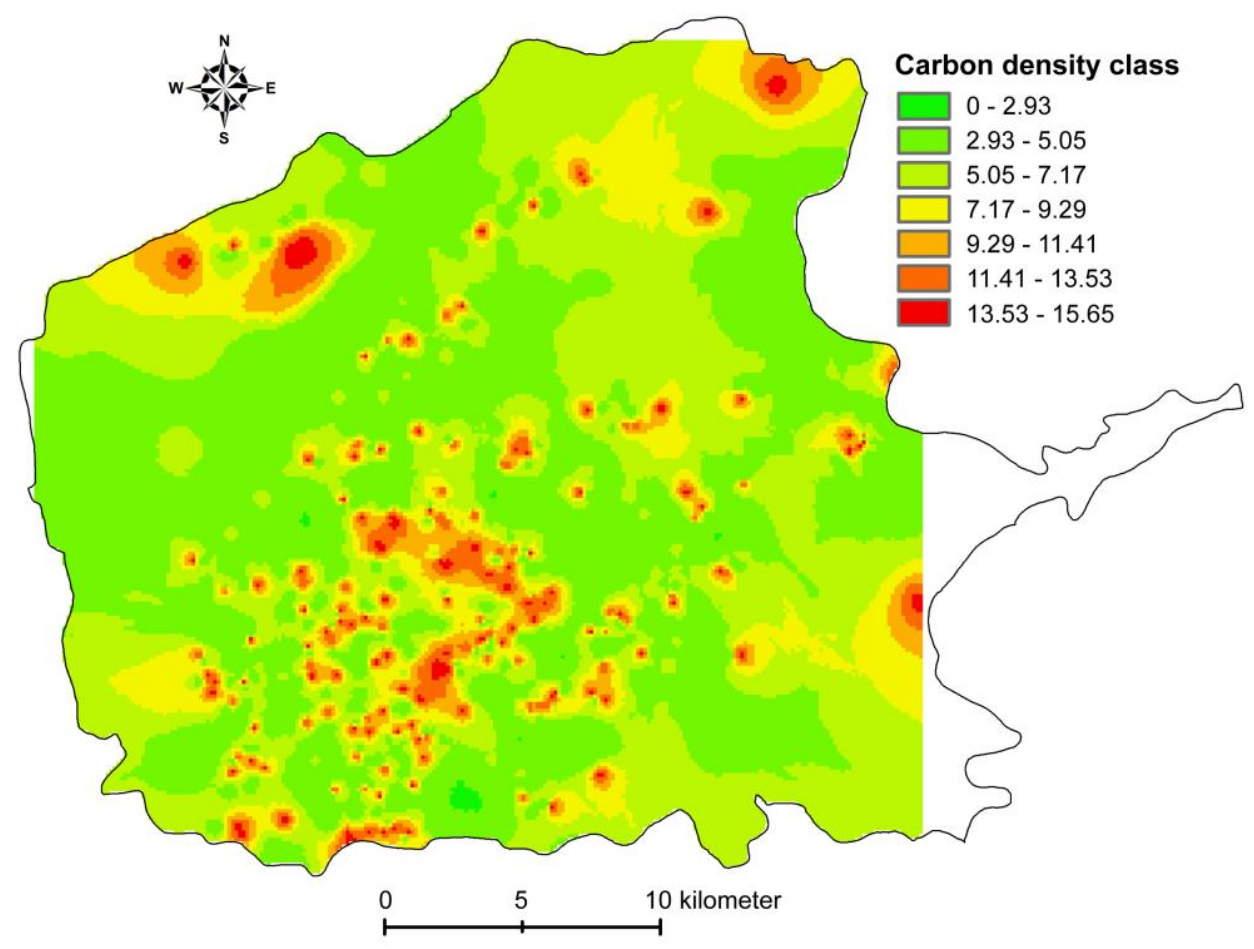

Figure 5. Spatial distribution of carbon density of arbor forest in Xi'an 
It can be seen from Figure 5 that areas with high carbon density of urban forest in Xi'an were mainly concentrated in the southern suburb of Xi'an. Individual parks and communities had high carbon density in the eastern and northern suburbs, but the overall level was general; the carbon density level in the western suburb was the lowest. In short, the carbon density of arbor forest in the main urban area of Xi' an showed the characteristics of high value in the southern suburb and low value in the northern suburb. This was closely related to the irrational distribution of green space, especially the unbalanced distribution of park green space. The distribution of park green space in the southern suburb was reasonable, with the eastern suburb was second. In contrast, the park green space in the western and northern suburbs had many defects. In addition, the cultural and educational areas in the southern suburb had more green space (six times that of the northern suburb and three times that of the western suburb); therefore, Xi' an should take great efforts to increase afforestation, especially in the eastern, western, and northern suburbs. For this, the government should strengthen the construction of large green corridors and accelerate the construction of a Xingfu forest belt along Xingfu Road, increase the quantity of three-dimensional urban green space, and strive to make Xi' an a forest city.

According to analysis of ARCGIS, the carbon density of arbor forest in the main urban area of Xi'an (0-2.93) accounted for $0.2 \%$, and $43.6 \%$ was between 2.93-5.05, $36.0 \%$ between $5.05-7.17,11.8 \%$ between $7.17-9.29,4.9 \%$ between $9.29-11.41,2.9 \%$ between 11.41-13.53, and $0.7 \%$ between 13.53-15.65. The research showed that the carbon density within the arbor forest in Xi'an was mainly concentrated in the range $2.93-7.17 \mathrm{~kg} / \mathrm{m}^{2}$.

\section{Analysis on carbon storage and carbon density of arbor forest in each Xi'an administrative region}

Spatial analysis on carbon storage and carbon density of arbor forest in each administrative region

Based on the data about carbon storage and carbon density in the arbor layer in six administrative regions of the main urban area in Xi'an, and by applying the analysis software ARCGIS10.2, the author carried out geographic space analysis on carbon storage and carbon density of arbor forest in the main urban area (Beilin District, Yanta District, Xincheng District, Lianhu District, Baqiao District, and Weiyang District). Also obtained was the spatial distribution of the carbon storage and carbon density in the arbor layer in each Xi' an administrative region (Fig. 6).

It can be seen from Figure 6 that the distribution of carbon density in the arbor layer in each Xi'an administrative region was characterized by high carbon density in the southern suburbs and low carbon density in the northern suburbs. The order of average carbon density in the arbor forest in each administrative region was Beilin District > Xincheng District > Lianhu District > Yanta District > Baqiao District > Weiyang District. The distribution of carbon storage in the arbor layer in each Xi'an administrative region is characterized by high carbon storage in the southern suburbs and low carbon density in the western suburbs. The order of average carbon storage in the arbor forest in each administrative region was Yanta District > Beilin District > Weiyang District $>$ Baqiao District $>$ Lianhu District $>$ Xincheng District. The research showed that Beilin District had superior carbon storage and carbon density because of substantial development, well-developed economy, and concentration of schools 
(especially colleges and universities) in Beilin District. The carbon storage in arbor forest of Lianhu District in the western suburbs and Xincheng District in the eastern suburbs was relatively low. The carbon density in the Weiyang District in the northern suburbs was also low, and needs to be improved further. It can be seen from Table 3 that in the six administrative regions, the area of Beilin District is the smallest and the population density is the highest. At the same time, its average carbon density is the highest $\left(8.39 \mathrm{~kg} / \mathrm{m}^{2}\right)$, which indicated that the age of the forest and area of forest land are factors that directly affect carbon density and carbon storage. In contrast, population density and human disturbance are indirect factors that affect carbon density and carbon storage. The ratio of area of land to carbon storage is 1/1.18 in Xincheng District, 1/4.92 in Beilin District, 1/1.15 in Lianhu District, 1/0.32 in Baqiao District, 1/0.41 in Weiyang District, and 1/1.13 in Yanta District. It can be seen that Baqiao District and Weiyang District need to increase the area of green space on the existing land area, especially the area of arbor forest.

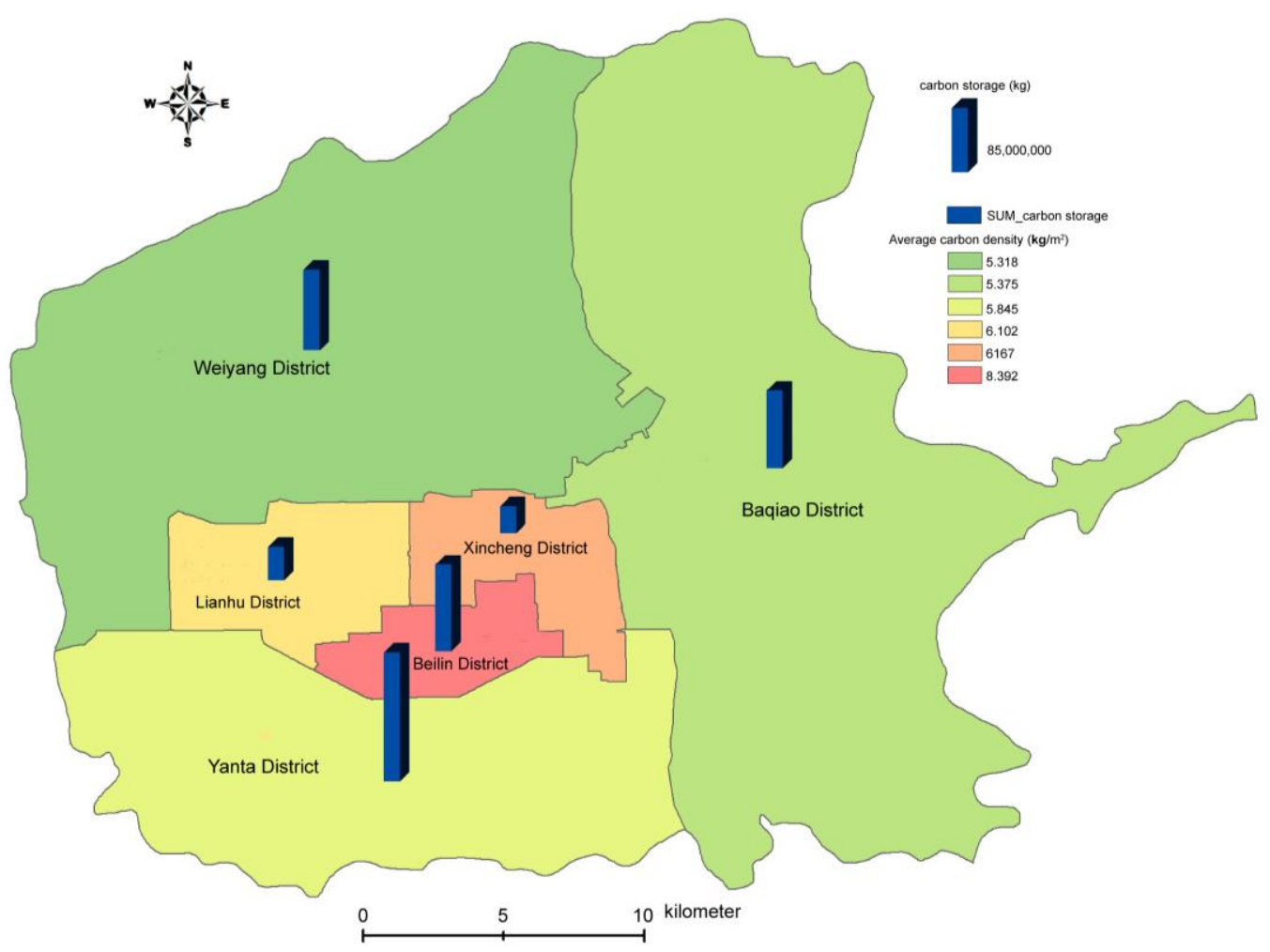

Figure 6. Spatial distribution of carbon storage and carbon density of arbor forest in each $X i$ 'an administrative region

Spatial analysis on carbon storage and carbon density of arbor forest in different functional areas of each administrative region

By applying ARCGIS software, the author showed the spatial distribution of carbon storage and carbon density in five types of green space in six Xi'an administrative regions, including road green space, residential area, scenic area-green space, cultural and educational green space, and industrial green space, as shown in Figures 7 and 8. The detailed information about the spatial distribution of carbon density of each type of green space in each Xi'an administrative region is shown in Table 3. 


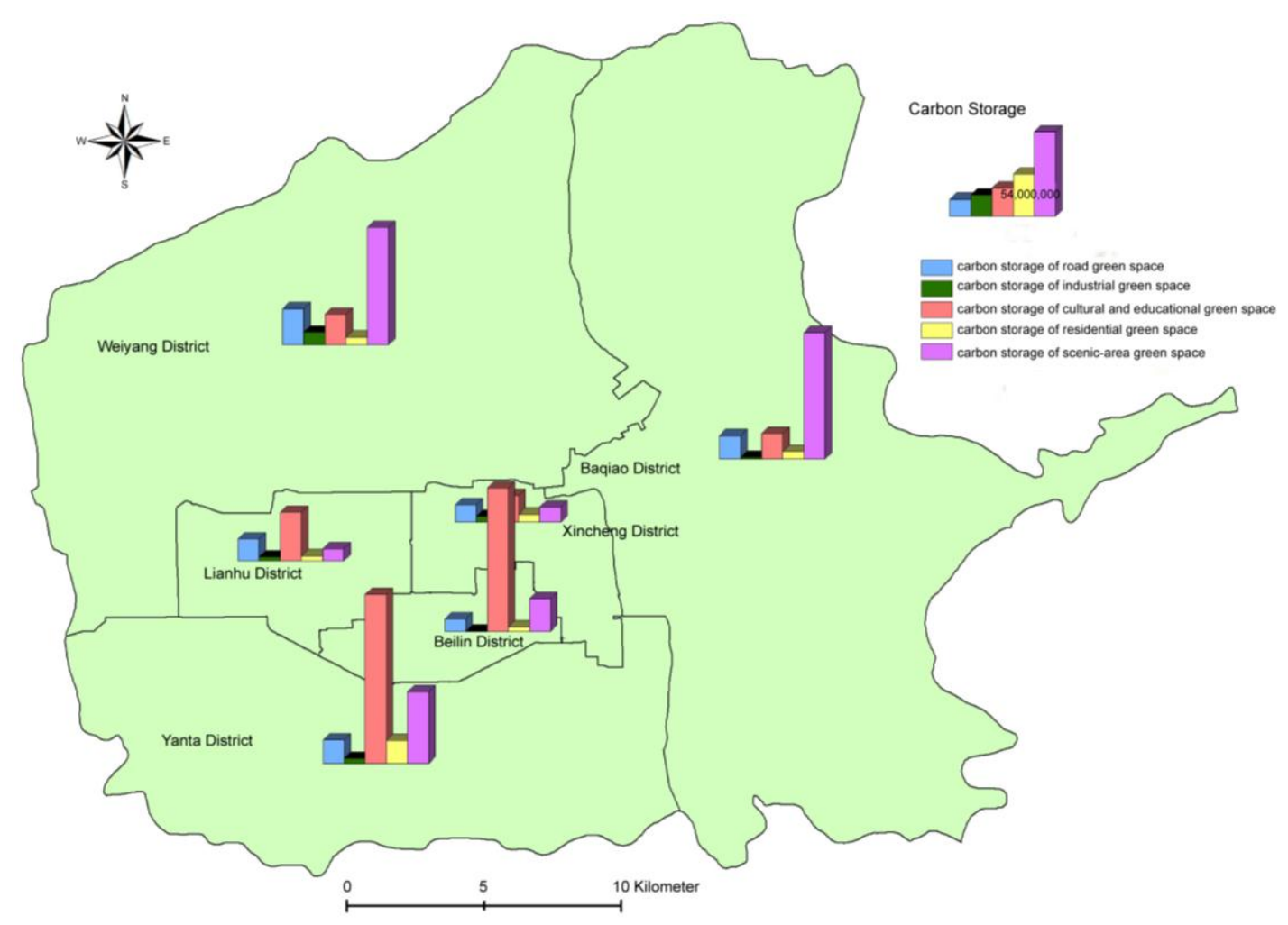

Figure 7. Spatial distribution of carbon storage of green space in each Xi'an Administrative region

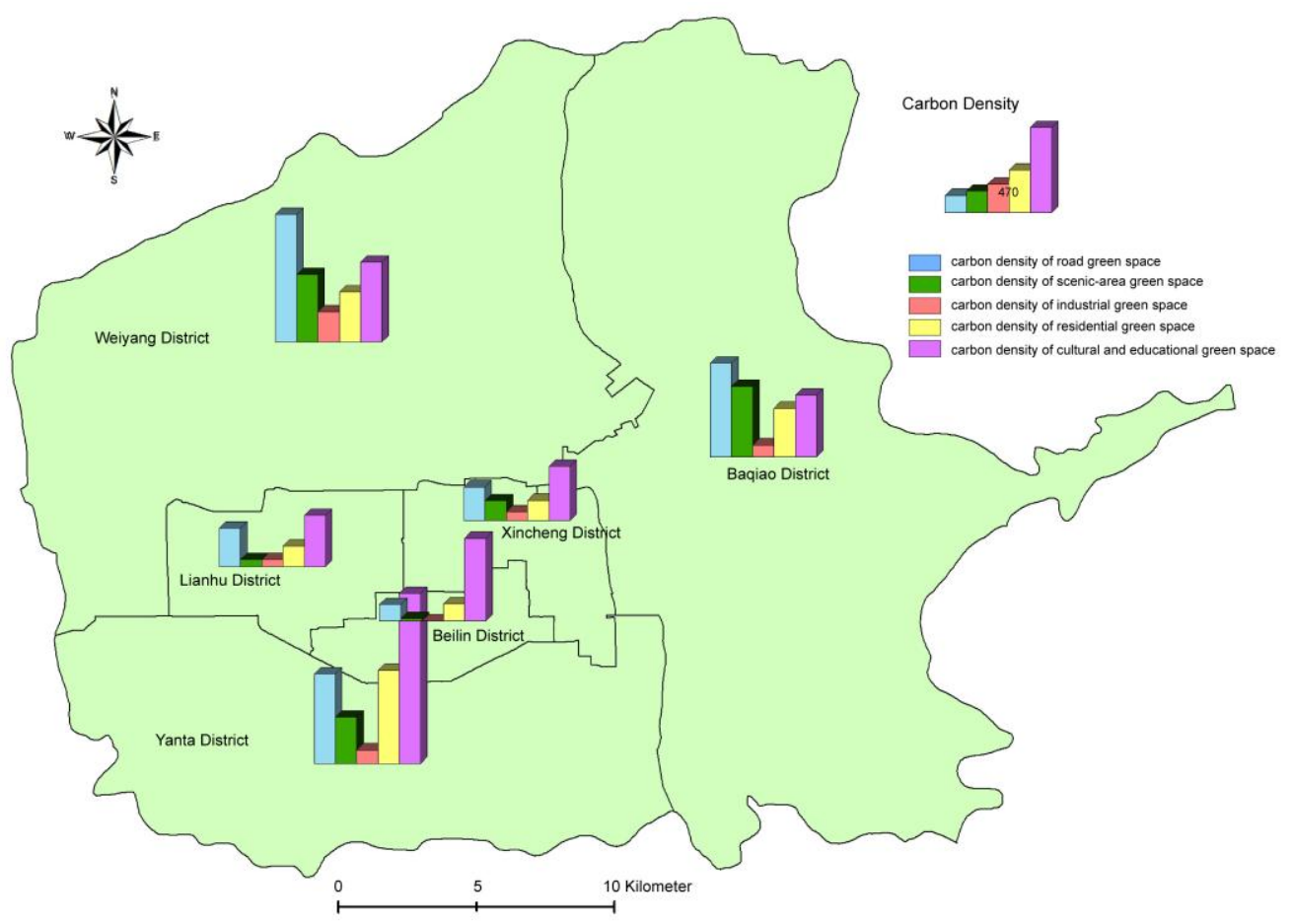

Figure 8. Spatial distribution of carbon density of green space in each Xi'an Administrative region 
Table 3. Carbon storage of green space types in Xi'an administrative region

\begin{tabular}{|c|c|c|c|c|c|c|c|c|c|c|c|c|c|c|c|}
\hline \multirow{2}{*}{$\begin{array}{l}\text { Administrative } \\
\text { region }\end{array}$} & \multicolumn{3}{|c|}{ Road green space } & \multicolumn{3}{|c|}{ Residential green space } & \multicolumn{3}{|c|}{ Scenic-area green space } & \multicolumn{3}{|c|}{$\begin{array}{c}\text { Cultural and educational green } \\
\text { space }\end{array}$} & \multicolumn{3}{|c|}{ Industrial green space } \\
\hline & $\begin{array}{c}\text { Area } \\
\left(\mathbf{m}^{2}\right)\end{array}$ & $\begin{array}{c}\text { Carbon } \\
\text { storage } \\
(\mathrm{kg})\end{array}$ & $\begin{array}{l}\text { Carbon } \\
\text { density } \\
\left(\mathrm{kg} / \mathrm{m}^{2}\right)\end{array}$ & $\begin{array}{c}\text { Area } \\
\left(\mathbf{m}^{2}\right)\end{array}$ & $\begin{array}{c}\text { Carbon } \\
\text { storage } \\
(\mathrm{kg})\end{array}$ & $\begin{array}{l}\text { Carbon } \\
\text { density } \\
\left(\mathrm{kg} / \mathrm{m}^{2}\right)\end{array}$ & $\begin{array}{c}\text { Area } \\
\left(\mathbf{m}^{2}\right)\end{array}$ & $\begin{array}{c}\text { Carbon } \\
\text { storage } \\
(\mathrm{kg})\end{array}$ & $\begin{array}{l}\text { Carbon } \\
\text { density } \\
\left(\mathbf{k g} / \mathbf{m}^{2}\right)\end{array}$ & $\begin{array}{l}\text { Area } \\
\left(\mathbf{m}^{2}\right)\end{array}$ & $\begin{array}{c}\text { Carbon } \\
\text { storage } \\
(\mathrm{kg})\end{array}$ & $\begin{array}{l}\text { Carbon } \\
\text { density } \\
\left(\mathrm{kg} / \mathrm{m}^{2}\right)\end{array}$ & $\begin{array}{c}\text { Area } \\
\left(\mathbf{m}^{2}\right)\end{array}$ & $\begin{array}{c}\text { Carbon } \\
\text { storage } \\
(\mathrm{kg})\end{array}$ & $\begin{array}{l}\text { Carbon } \\
\text { density } \\
\left(\mathrm{kg} / \mathrm{m}^{2}\right)\end{array}$ \\
\hline $\begin{array}{l}\text { Xincheng } \\
\text { District }\end{array}$ & 57250.01 & 10627891.08 & 185.64 & 45232.66 & 5036204.27 & 111.34 & 88306.90 & 9622811.15 & 108.97 & 56963.12 & 17034250.39 & 299.04 & 79003.43 & 3792164.62 & 48.00 \\
\hline $\begin{array}{l}\text { Beilin } \\
\text { District }\end{array}$ & 87835.39 & 7943832.77 & 90.44 & 29274.09 & 2744738.47 & 93.76 & 1623101.0 & 20808151.18 & 12.82 & 200469.20 & 91349788.07 & 455.68 & 0.00 & 0.00 & 0.00 \\
\hline $\begin{array}{l}\text { Lianhu } \\
\text { District }\end{array}$ & 65773.95 & 14088780.57 & 214.20 & 27305.66 & 3120217.72 & 114.27 & 203859.80 & 7840447.57 & 38.46 & 108262.10 & 30833048.35 & 284.80 & 63920.84 & 2454560.27 & 38.40 \\
\hline $\begin{array}{l}\text { Baqiao } \\
\text { District }\end{array}$ & 29080.89 & 15088328.73 & 518.84 & 18368.02 & 4951283.56 & 269.56 & 206459.70 & 80727810.54 & 391.01 & 47549.84 & 16250633.65 & 341.76 & 16383.51 & 1100971.57 & 67.20 \\
\hline $\begin{array}{l}\text { Weiyang } \\
\text { District }\end{array}$ & 32352.99 & 22792033.26 & 704.48 & 17804.33 & 4903667.32 & 275.42 & 201518.0 & 74920380.11 & 371.78 & 43961.57 & 19406395.88 & 441.44 & 47578.50 & 7917063.03 & 166.40 \\
\hline $\begin{array}{c}\text { Yanta } \\
\text { District }\end{array}$ & 30095.94 & 14898694.69 & 495.04 & 28548.67 & 14638333.0 & 512.75 & 177780.0 & 45582801.39 & 256.40 & 114551.90 & 107660462.11 & 939.84 & 40400.94 & 2973509.11 & 73.60 \\
\hline
\end{tabular}


It can be seen in Figures 7 and 8 and Table 3 that the carbon storage capacity of each type of green space occurred in the order cultural and educational green space $>$ road green space $>$ scenic-area green space $>$ residential green space $>$ industrial green space in Xincheng District. In Belin District, the order was cultural and educational green space > scenic-area green space > road green space > residential green space > industrial green space. The order was cultural and educational green space $>$ road green space > scenic-area green space > residential green space > industrial green space in Lianhu District; but scenic-area green space > cultural and educational green space > road green space $>$ residential green space $>$ industrial green space in Baqiao District. For Weiyang District, the order was scenic-area green space > road green space > cultural and educational green space > industrial green space > residential green space; and cultural and educational green space $>$ scenic-area green space $>$ road green space $>$ residential green space > industrial green space in Yanta District.

The carbon density of each green space type occurred in the order cultural and educational green space > road green space > residential green space > scenic-area green space > industrial green space in Xincheng District; cultural and educational green space > residential green space > road green space > scenic-area green space > industrial green space in Beilin District, and cultural and educational green space $>$ road green space $>$ residential green space $>$ scenic-area green space $>$ industrial green space in Lianhu District. For Baqiao District the order was road green space > scenic-area green space $>$ cultural and educational green space $>$ residential green space $>$ industrial green space; while in Weiyang District it was road green space > cultural and educational green space $>$ scenic-area green space $>$ residential green space $>$ industrial green space; and finally, in Yanta District, the order was cultural and educational green space > residential green space > road green space > scenic-area green space > industrial green space.

The research showed that the spatial distribution of carbon storage and carbon density of arbor forest in Xi'an is not balanced; it is high in the southern suburbs and low in the northern suburbs. The greatest contribution rate of carbon storage occurred in the cultural and educational green space in Yanta District, followed by the cultural and educational green space in Beilin District, scenic-area green space in Baqiao District, and scenic-area green space in Weiyang District, respectively. The least contribution rate of carbon storage was in residential green space in Weiyang District, in which the construction of residential green space should be increased.

\section{Discussion}

In the twentieth century, the urbanization process has been accelerated, the urban population in the world has increased by 10 times, and the proportion of urban population has risen from $14 \%$ to $50 \%$. It is estimated that by 2030 , more than $60 \%$ of the world's population will live in cities. As of 2010, the proportion of urban population in China reached $49.68 \%$ and the spatial expansion of the area used for urban and town land use will increasingly become the main feature of land use change in China in the next few decades (Minghong et al., 2004). This rapid expansion of cities, and the evolution of land use patterns, will have a profound impact on conditions for urban plants, further affecting their distribution pattern, species composition, and diversity. The temporal and spatial evolution of land use has been 
characterized by rapid and intense expansion of land under construction and the occupation of a large amount of arable land.

At present, more than $50 \%$ of the world population lives in cities, and the cities that account for $2 \%$ of the land area now emit $78 \%$ of the greenhouse gases (Grimm, et al., 2000). The amount of $\mathrm{CO}_{2}$ produced in urban regions is believed to be greater, accounting for $96 \%$ to $98 \%$ of total emissions (IPCC, 2000). The urban expansion in $\mathrm{Xi}$ 'an was quite rapid, more than $10 \%$ of the annual growth rate. At present, the area of current urban regions is over $1,000 \mathrm{~km}^{2}$, and the rapid development of urbanization has brought severe challenges to the urban ecological environment. These have restricted improvements of quality of life for residents and of further development of urbanization. What is more, urban heat island effect, environmental pollution, greenhouse effects, traffic jams, and other ecological and environmental problems are constant. Forest carbon sequestration plays an important role in mitigating global climate change. Carbon sequestration is of great importance in reducing the greenhouse gas concentration in the atmosphere and slowing global warming. Therefore, urban ecosystems play important roles in the global carbon cycle.

At present, there are still large uncertainties in the estimation of soil carbon sequestration and vegetation carbon sequestration, especially the carbon sequestration by scrub-grassland and trees that are outside of forests. In addition, the R\&D on the atmosphere inversion model that accords with China's actual situation can not only simulate the amount and distribution of carbon sequestration, but can also predict future carbon sequestration scientifically (Fang et al., 2007).

Human activity is an important factor affecting the spatial distribution of the quantity and density of carbon stored in forest vegetation. At the same time, plant abundance, evenness, and diversity are drivers of carbon storage in forest vegetation. The carbon stored in the Xi'an forest vegetation plays an important role in regional carbon balance and cycle. Furthermore, the carbon stored in the arbor forest in Xi'an is almost proportional to the diameter at breast height (D) and the height $(\mathrm{H})$ of the trees; therefore, the carbon density of forest in Xi'an is closely related to the age of the forest.

The quantity and density of the carbon stored in the Xi'an forest vegetation are relatively low because it has a relatively large proportion of young and middle-aged forests. There is great potential for carbon sequestration in the Xi'an forest vegetation in the future. Carbon storage in forest vegetation is the basis for measuring the ecological benefits of forests and a key indicator with which to measure ecological construction. The quality of the forest structure in $\mathrm{Xi}$ 'an needs to be improved further, and the protection of urban species diversity strengthened, so that the ecosystem services of the forest city can be expanded to its fullest.

\section{Conclusion}

Through investigation of 240 quadrats from 113 roads, 20 parks, 23 residential quarters, 18 schools, and 6 industrial zones in $\mathrm{Xi}$ 'an, 68 tree species were found in the main urban area in Xi'an. The predominant tree species were Platanus orientalis, Styphnolobium japonicum (L.) Schott (Chinese scholar tree), and Ligustrum lucidum. The entire group of trees belonged to 36 families and 63 genera; and accounted for $64.57 \%$ of the total vegetation. The ratio of evergreen tree species to deciduous tree species was 2:9, of which deciduous tree species mainly included 50 species 
(including the Chinese scholar tree and the ginkgo (Ginkgo biloba) belonging to 30 families and 44 genera, and accounting for $81.22 \%$. Evergreen tree species included 18 species (including Cedrus deodara, Magnolia grandiflora, and Ligustrum lucidum) belonging to 11 families and 19 genera, and accounting for $18.78 \%$. In general, there was a smaller number of evergreen plants in Xi'an and the proportion was not balanced. Based on the high-resolution satellite remote-sensing image data, by combining with $3 \mathrm{~S}$ technology (GIS, RS, and GPS) and applying measurements from actual quadrats, the author carried out accurate estimation of carbon density and total carbon storage by forest vegetation in the main urban area of Xi'an. Then, the author carried out quantitative analysis of the spatial distribution of carbon storage and carbon density in arbor forest in the main urban area of $\mathrm{Xi}$ 'an using the analysis software ARCGIS10.2. This was used to analyze the spatial distribution of carbon storage and carbon density in the arbor layer in each $\mathrm{Xi}$ 'an administrative region. From the research results discussed data, the findings are as follows.

(1) The average carbon density in the arbor layer of each type of green space in the main urban area of Xi'an occurred in the order cultural and educational green space > scenic-area green space > road green space > industrial green space > residential green space; and the average carbon density in the arbor layer in the main urban area of Xi'an was $6.308 \mathrm{~kg} / \mathrm{m}^{2}$, which is higher than that in Shaanxi Province. The average carbon storage in the arbor layer of each green space type in the main urban area of Xi'an occurred in the order cultural and educational green space $>$ scenic-area green space $>$ road green space $>$ residential green space $>$ industrial green space. The carbon storage in the cultural and educational green space was $210,990 \mathrm{t} \mathrm{C}$, accounting for $40.6 \%$ of the arbor layer carbon sequestration in the main urban area. The carbon storage in scenic-area green space contributed $35.1 \%$ to the carbon sequestration of the arbor layer in the whole city. The carbon storage in the road green space accounted for $14.3 \%$ of total carbon storage of the arbor layer in the whole city and the carbon storage in the residential green space accounted for $6.6 \%$ of total carbon storage of arbor in the whole city. Carbon storage in the industrial green space accounted for only $3.3 \%$ of total carbon storage of the arbor layer in the whole city. The total amount of carbon storage in the arbor layer in the main Xi' an urban area was 519,180 t C.

(2) The distribution of carbon density of arbor layer in each Xi' an administrative region is characterized by high carbon density in the southern suburbs and low carbon density in the northern suburbs, and the average carbon density of arbor forest in each administrative region was in the order Beilin District $>$ Xincheng District $>$ Lianhu District > Yanta District > Baqiao District > Weiyang District. The distribution of carbon storage in the arbor layer in each Xi' an administrative region is characterized by high carbon storage in the southern suburbs and low carbon density in the western suburbs, and the average carbon storage in arbor forest in each administrative region was in the order Yanta District > Beilin District $>$ Weiyang District $>$ Baqiao District $>$ Lianhu District > Xincheng District.

(3) The carbon storage capacity of each type of green space was in the order cultural and educational green space $>$ road green space $>$ scenic-area green space $>$ residential green space $>$ industrial green space in Xincheng District; cultural and educational green space $>$ scenic-area green space > road green space > residential green space > industrial green space in Beilin District; cultural and educational green space $>$ road green space $>$ scenic-area green space $>$ residential green space $>$ industrial green space in Lianhu District; scenic-area green space > cultural and educational green space > 
road green space > residential green space > industrial green space in Baqiao District; scenic-area green space > road green space > cultural and educational green space > industrial green space $>$ residential green space in Weiyang District, and cultural and educational green space > scenic-area green space > road green space > residential green space $>$ industrial green space for Yanta District.

(4) The carbon density of each type of green space occurred in the order cultural and educational green space > road green space > residential green space > scenicarea green space > industrial green space in Xincheng District; cultural and educational green space > residential green space > road green space > scenic-area green space > industrial green space in Beilin District; cultural and educational green space > road green space > residential green space > scenic-area green space > industrial green space in Lianhu District; road green space $>$ scenic-area green space $>$ cultural and educational green space $>$ residential green space $>$ industrial green space in Baqiao District; road green space > cultural and educational green space > scenicarea green space > residential green space > industrial green space in Weiyang District; and cultural and educational green space > residential green space > road green space > scenic-area green space > industrial green space in Yanta District.

(5) The greatest contribution rate of carbon storage occurred in the order cultural and educational green space in Yanta District, followed by cultural and educational green space in Beilin District, scenic-area green space in Baqiao District, and scenicarea green space in Weiyang District. The least contribution rate of carbon storage was by residential green space in Weiyang District. In general, the spatial distribution of carbon storage and carbon density in Xi'an is not balanced: high in the southern suburbs and low in the northern suburbs.

In summary, the forest vegetation in Xi'an has great potential for carbon sequestration. The results showed that the average carbon density of arbor trees in the main urban area of Xi' an was $6.308 \mathrm{~kg} / \mathrm{m}^{2}$, which is higher than the average carbon density in Shaanxi Province $\left(3.092 \mathrm{~kg} / \mathrm{m}^{2}\right)$. Moreover, the arbor forest of Xi'an makes a great contribution to the forest carbon sequestration in Shaanxi Province, playing a key role in whole-province forest sequestration. Because of the characteristics of the geographical environment in Xi'an, the fragile ecological environment and serious soil erosion, an effective approach would be to increase forest vegetation, improve the quality of forest structure, increase the quantity of three-dimensional greenery, and manage forest vegetation with attention to detail, to improve the urban environment and enhance forest carbon sequestration. This would improve the ability of the urban forest to fulfill its ecological service functions. In the future, based on the remote sensing image data and use of large-scale quadrats, the existing database will be updated via GIS, and an inversion model suitable for the actual situation in each region will provide a direction for developing more accurate assessment of regional forest carbon sequestration.

Acknowledgements. The research was funded by the National Natural Science Foundation of China (51608419) and the Shaanxi Provincial Natural Science Foundation (2014JZ011). 


\section{REFERENCES}

[1] Beer, C., Reichstein, M., Tomelleri, E., Jung, M., Carvalhais, N., Rödenbeck, C., Arain, M. A., Baldocchi, D., Bonan, G. B., Bondeau, A., Cescatti, A., Lasslop, G., Lindroth, A., Lomas, M., Luyssaert, S., Margolis, H., Oleson, K. W., Roupsard, O., Veenendaal, E., Viovy, N., Williams, C., Woodward, F. I., Papale, D. (2010): Terrestrial gross carbon dioxide uptake: global distribution and covariation with climate. - Science 329: 834-838.

[2] Bonan, G. B. (2008): Forests and climate change: forcings, feedbacks, and the climate benefits of forests. - Science 320: 1444-1449.

[3] Bousquet, P., Peylin, P., Ciais, P., Le Quéré, C., Friedlingstein, P., Tans, P. P. (2000): Regional changes in carbon dioxide fluxes of land and oceans since 1980. - Science 290: 1342-1346.

[4] Coley, R. L., Sullivan, W. C., Kuo, F. E. (1997): Where does community grow? The social context created by nature in urban public housing. - Environment \& Behavior 29: 468-494.

[5] Dixon, R. K, Solomon, A. M., Brown, S., Houghton, R. A., Trexier, M. C., Wisniewski, J. (1994): Carbon pools and flux of global forest ecosystems. - Science 262: 185-190.

[6] Dongsheng, G., Yujuan, C., Fenfang, H. (1998): The storage and distribution of carbon in urban vegetation and its role in balance of carbon and oxygen in Guangzhou 1998. China Environmental Science 18: 437-441.

[7] Fang, J. Y. (2000): Forest biomass carbon pool of the middle and high latitudes in North Hemisphere is probably much smaller than present estimates. - Acta Phytoecologica Sinica 24: 635-638.

[8] Fang, J. Y., Guo, Z. D., Pu, S. L., Chen, A. P. (2007): Estimation of carbon sequestration of terrestrial vegetation in China from 1981-2000. - Science in China (Series-D: Earth Sciences) 37: 804-812.

[9] Fang, J. Y., Chen, A. P., Peng, C. H., Zhao, S., Ci, L. (2001): Changes in forest biomass carbon storage in China between 1949 and 1998. - Science 292: 2320-2322.

[10] Ge, Z., Zhou, D., He, Y., Chen, P., Guan, Q. (2013): Current status of arborous carbon storage in urban green space of Xuzhou City. - China Forestry Science and Technology 27: 30-34.

[11] Grimm, N. B., Grove, J. M., Pickett, S. T. A., Redman, C. L. (2000): Integrated approaches to long-term studies of urban ecological systems. - BioScience 50: 571-584.

[12] Houghton, J. T., Meira Filho, L. G., Bruce, J., Lee, H., Callander, B. A., Haites, E., Harris, N., Maskell, K. (eds.) (1994): Climate Change 1994: Radiative Forcing of Climate Change and an Evaluation of the IPCC IS92 Emission Scenarios. - Cambridge University Press, Cambridge, UK.

[13] Huang, C. D., Zhang, J., Yang, W. Q., Tang, X., Zhang, G. Q. (2009): Spatial differentiation characteristics of forest vegetation carbon stock in Sichuan Province. Acta Ecologica Sinica 29: 5115-5121.

[14] Intergovernmental Panel on Climate Change (IPCC) (2000): Emission Scenarios. - In: Nakicenovic, N., Swart, R. (eds.) Special Report on Emission Scenarios. Cambridge University Press, Cambridge, UK.

[15] Janssens, I. A., Freibauer, A., Ciais, P., Smith, P., Nabuurs, G. J., Folberth, G., Schlamadinger, B., Hutjes, R. W. A., Ceulemans, R., Schulze, E. D., Valentini, R., Dolman, A. J. (2003): Europe's terrestrial bio-sphere absorbs 7 to 12\% of European anthropgenic CO2 emission. - Science 300: 1538-1542.

[16] Jo, H. K., Mcpherson, G. E. (1995): Carbon storage and flux in urban residential green space. - Journal of Environmental Management 45: 109-133.

[17] Liu, G., Fu, B., Fang, J. (2000): Carbon dynamics of Chinese forests and its contribution to global carbon balance. - Acta Ecologica Sinica 20: 733-740. 
[18] Liu, Z., Li, B., Fang, X., Xiang, W., Tian, D., Yan, W., Lei, P. (2016): Dynamic characteristics of forest carbon storage and carbon density in Hunan Province. - Acta Ecologica Sinica 36: 6897-6908.

[19] Ma, Q., Liu, K., Zhang, H. (2012): Carbon storage by forest vegetation and its spatial distribution in Shaanxi. - Resources Science 34: 1781-1789.

[20] Mcpherson, E. G. (1998): Atmospheric carbon dioxide reduction by Sacramento's urban forest. - Journal of Arboriculture 24: 215-223.

[21] Minghong, T., Xiubin, L., Changhe, L. (2004): Expansion of construction land in China's Large and medium-sized cities in the 1990s and its occupation of cultivated land. Science in China (Series-D: Earth Sciences) 34: 1157-1165.

[22] Niemelä, J., Saarela, S. R., Söderman, T., Kopperoinen, L., Yli-Pelkonen, V., Väre, S., Kotze, D. J. Soderman, T. (2010): Using the ecosystem services approach for better planning and conservation of urban green spaces: a Finland case study. - Biodiversity and Conservation 19: 3225-3243.

[23] Nowak, D. J. (1993): Atmospheric carbon reduction by urban tree. - Environmental Management 37: 207-217.

[24] Nowak, D. J., Crane, D. E. (2002): Carbon storage and sequestration by urban trees in the USA. - Environmental Pollution 116: 381-389.

[25] Pacala, S. W., Hurtt, G. C., Baker, D., Peylin, P., Houghton, R. A., Birdsey, R. A., Heath, L., Sundquist, E. T., Stallard, R. F., Ciais, P., Moorcroft, P., Caspersen, J. P., Shevliakova, E., Moore, B., Kohlmaier, G., Holland, E., Gloor, M., Harmon, M. E., Fan, S. M., Sarmiento, J. L., Goodale, C. L., Schimel, D., Field, C. B. (2001): Consistent landand atmosphere-based US carbon sink estimates. - Science 292: 2316-2320.

[26] Piao, S. L., Fang, J. Y., Zhu, B., Tan, K. (2005): Forest biomass carbon stocks in China over the past 2 decades: estimation based on integrated inventory and satellite data. Journal of Geophysical Research 110: G01006.

[27] Siegenthaler, U., Sarmiento, J. L. (1993): Atmospheric dioxide and the ocean. - Nature 365: 119-125.

[28] Tans, P. P., Fung, I. Y., Takahashi, T. (1990): Observational constraints on the global atmospheric $\mathrm{CO}_{2}$ budget. - Science 247: 1431-1438.

[29] Wang, X., Feng, Z., Ouyang, Z. (2001): Vegetation carbon storage and density of forest ecosystems in China. - Chinese Journal of Applied Ecology 12: 13-16.

[30] Yan, S., Ying, G., Hexian, J., Yuan, R., Zelong, Q., Zhiyi, B., Jie, C. (2016): Progress in studies on carbon sequestration of urban vegetation. - Scientia Silvae Sinicae 52: 122129.

[31] Zhen, W., Huangmei, M., Zhai, Y., Chen, K., Gong, Y. Z. (2014): Variation of forest vegetation carbon storage and carbon sequestration rate in Liaoning Province, Northeast China. - Chinese Journal of Applied Ecology 25: 1259-1265. 